\title{
Species of Rumen Ciliate Protozoa \\ Which Produce Extra-Cellular Protease \\ and Influence of Bacteria on Its Activity
}

\author{
Shuji Shinchi and Matanobu ABE \\ School of Veterinary Medicine, Azabu University, \\ Sagamihara-shi 229
}

(Received July 14, 1986)

\begin{abstract}
In vitro experiments were done in order to identify the species of rumen ciliate protozoa which produce proteolytic enzymes outside the cell and the effect of contaminated bacteria on the extra-cellular proteolytic activity. Bacteria and ciliate protozoa were isolated from the rumen liquid obtained from a Holstein cow through the fistula, and protozoa were separated into two groups of entodiniomorphs and holotrichs. The extra-cellular crude enzyme solutions were prepared by centrifuging the starved culture medium of each protozoa group and of isolated bacteria, and the proteolytic activity was assayed through the decomposition of casein incubated with crude enzyme preparations. The results obtained are summarized as follows : 1) Extra-cellular proteolytic activity was detected exclusively in the culture medium of entodiniomorphs, and not in the medium of holotrich protozoa. 2) Isolated bacteria decomposed casein, but the proteolytic activity was hardly detected in the cell-free medium prepared after the culture of bacterial suspension. 3) Extra-cellular proteolytic activity detected for entodiniomorphid protozoa was not modified by washing these organisms several times with surface-active substance (sugar-fatty acid ester) to eliminate bacteria, which may attach to the surface of ciliate protozoa. 4) the results of this work suggest that the extra-cellular proteolytic activity would be principally attributed to entodiniomorphid protozoa, and that the influence of bacteria could be neglected.
\end{abstract}

Jpn. J. Zootech. Sci., 58 (1): 72-79, 1987

Key words : rumen, ciliate protozoa, bacteria, extra-cellular, protease

UEDA et al. ${ }^{1)}$ suggested that the rumen ciliate protozoa may secrete peptidase into the medium during in vitro incubation. SHINCHI and Kandatsu showed that the rumen ciliate protozoa excrete the extra-cellular proteolytic enzymes into the culture medium during incubation with salt buffer solution ${ }^{2)}$, and examined on some properties of purified enzymes ${ }^{3)}$. Furthermore, they demonstrated a proteolytic activity in the cell-free rumen liquid ${ }^{4}$.

Rumen ciliate protozoa are roughly grouped into holotrichs and entodiniomorphs and it has been reported that the former decomposes both soluble and insoluble casein, but that the latter decomposes only insoluble casein ${ }^{5)}$. These experiments were done in order to investigate species of rumen ciliate protozoa which produce extra-cellular proteolytic enzymes and the effect of possible contamination of bacteria on the activity of these enzymes. 


\section{Mterials and Methods}

Doner of microorganisms : Rumen liquid was obtained from a rumen fistulated Holstein cow (4 year-old and weighing about $600 \mathrm{~kg}$ ), which was fed twice daily with rations consisting of $1.5 \mathrm{~kg}$ rice straw and $2 \mathrm{~kg}$ concentrate (commercial formula feed, CP 13.5\%) and given water ad libitum.

Fractionation of ciliate protozoa and isolation of bacteria : About 41 of rumen liquid were taken through the rumen fistula at $1 \mathrm{hr}$ after feeding in the morning and were strained through two layers of gauze. Fractions of entodiniomorphid protozoa, holotrich protozoa and isolated bacteria were prepared by the method shown in Fig. 1.

Preparation of microbial suspensions: Two ciliate protozoa fractions were suspended in $60 \mathrm{ml}$ of B-9 buffer solution ${ }^{6)}$ containing $50 \mu \mathrm{g}$ each of penicillin $\mathrm{G}$ potassium, streptomycin sulfate, kanamycin sulfate and chloromycetin powder per $\mathrm{ml}$, and isolated bacteria fraction was suspended in an original volume of the buffer solution with or without the same amounts of antibiotics.

Separation of bacteria attached to the surface of ciliate protozoa : One part of entodiniomorphid fraction was washed twice with $0.05 \%$ sugar-fatty acid ester solution by centrifugation $(160 \times \mathrm{g}$ for $3 \mathrm{~min}$ ), and then washed 5 times with B-9 buffer solution. Another part of the fraction was washed 7 times in succession with B-9 buffer solution by centrifugation ( $160 \times \mathrm{g}$ for $3 \mathrm{~min}$ ), and thereafter each fraction was suspended in $60 \mathrm{ml}$ of the buffer solution containing $50 \mu \mathrm{g}$ each of four antibiotics per $\mathrm{m} l$.

Preparation of extra-cellular crude enzyme solution: Thirty millilitres of protozoa and bacteria suspensions were cultured at $39^{\circ} \mathrm{C}$ without any substrate in a $100 \mathrm{~m} l$ ERLENMEYeR's flask sealed with rubber stopper after the air phase in the flask was

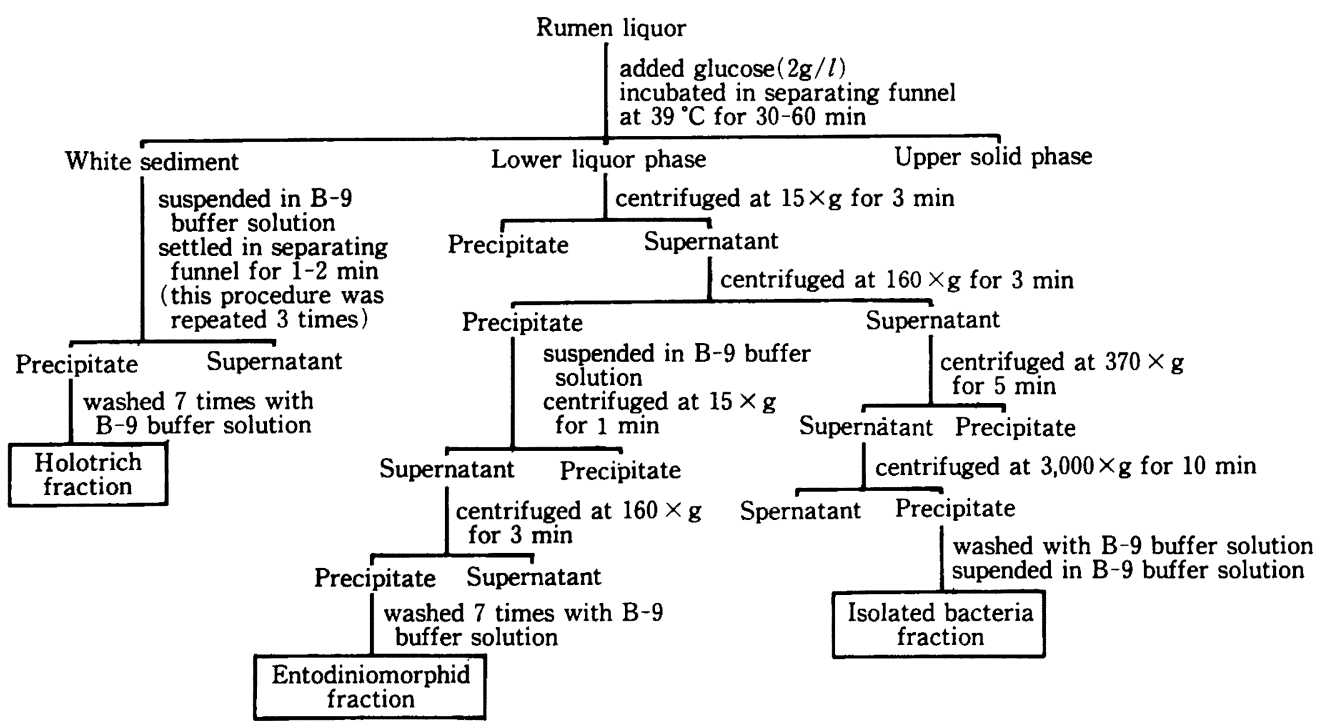

Fig. 1. Scheme for the fractionation of rumen ciliate protozoa and isolated bacteria. 
replaced by mixed gasses $\left(\mathrm{N}_{2}: \mathrm{CO}_{2}=95: 5\right)$. After $3 \mathrm{hr}$, the culture medium was centrifuged at $600 \times \mathrm{g}$ for $5 \mathrm{~min}$ to remove ciliate protozoa, and the supernatant fluid was further centrifuged at $27,000 \times \mathrm{g}$ for $40 \mathrm{~min}$ at $4^{\circ} \mathrm{C}$ to obtain the extra-cellular crude enzyme solution. As for bacteria, extra-cellular crude enzyme solutions were prepared after $30 \mathrm{ml}$ of bacteria suspensions with or without antibiotics were cultured for 3,8 and $20 \mathrm{hr}$ in a similar manner as above and centrifuged at $27,000 \times \mathrm{g}$ for $40 \mathrm{~min}$ at $4^{\circ} \mathrm{C}$.

Assay for extra-cellular protease : Two millilitres of crude enzyme solution and 2 $\mathrm{m} l$ of B- 9 buffer solution containing $0.08 \% \mathrm{NaN}_{3}$ and $4 \mathrm{mM}$ cysteine-HCI were added to $4 \mathrm{ml}$ of casein (Merk, for biochemistry) solution $(2 \mathrm{mg} \mathrm{N} / \mathrm{ml}$ ) immediately before the incubation at $39^{\circ} \mathrm{C}$. The reaction was stopped by adding $8 \mathrm{ml}$ of $20 \%$ trichloroacetic acid solution (final concentration : $10 \% \mathrm{~W} / \mathrm{V}$ ), and the mixture was filtrated by Whatman no. 50 paper. Non-protein nitrogen (NPN) was determined by the LowRY method as modified by HARTEREE ${ }^{7)}$.

Assay for proteolytic activity of isolated bacteria : One hundred millilitres of bacteria suspensions, with or without antibiotics, were cultured at $39^{\circ} \mathrm{C}$ with $709 \mathrm{mg}$ casein $(1 \mathrm{mg} \mathrm{N} / \mathrm{m} l$ ) in a $200 \mathrm{~m} l$ ERLENMEYER's flask replaced its air phase by mixed gasses and sealed with rubber stopper. Ten millilitres each of the culture medium were taken periodically, and the reaction was stopped by adding $10 \mathrm{ml}$ of $20 \%$ trichloroacetic acid solution. After the centrifugation at $27,000 \times \mathrm{g}$ for $30 \mathrm{~min}$ at $4^{\circ} \mathrm{C}$, NPN in the supernatant was determined by the above method.

Scanning electron microscopy : A small portion of entodiniomorphid fraction was dropped on the $6 \times 6 \mathrm{~mm}$ slide grass on which $1 \%$ poly-L-lysine solution was painted. Within $10 \mathrm{~min}$, ciliate protozoa stuck on the surface of the slide grass. The further treatments were the same as reproted by IMAI and ОGiмото ${ }^{8)}$. The fixed and dehydrated specimen was stuck on a sample stage with stage with double-sticking tape, and the surface was coated with a thin layer of platinum-vanasium in a rotating vacuume evaporator. These specimens were observed by a scanning electron microscope (model JSM-T 20 Hitachi Electronics Co.).

Determination of microbial nitrogen : Total nitrogen of microbial suspension was determined by KJELDAL method.

Counting of protozoa: Ciliate protozoa were counted with Tatai Eosinophil Counter after the microbial suspension was diluted five-fold with $\mathrm{FSH}^{9)}$.

\section{Results and Discussion}

SHINCHI et $a l .^{4)}$ showed that the cell-free rumen liquid has a proteolytic activity, and at least a part of the activity owes to the extra-cellular protease excreted by rumen ciliate protozoa. Proteolytic activity in cell-free rumen liquid was higher after feeding than before feeding, and the tendency was consistent with that of the variation of holotrich numbers in the rumen ${ }^{4}$. As shown in Table 1, however, extra-cellular proteolytic activity was found in the culture medium of entodiniomorphid fraction, but not in the medium of holotrich fraction. Although protozoa number in the culture 


\section{Rumen Protozoa Producing Extra-Cellular Protease}

Table 1. Proteolytic activity of extra-cellular crude enzyme solution of entodiniomorphid and holotrich protozoa

\begin{tabular}{lccccc}
\hline \hline & Incubation & \multicolumn{2}{c}{$\begin{array}{c}\text { NPN in incubation } \\
\text { medium }(\mu \mathrm{g} / \mathrm{m} l)\end{array}$} & \multicolumn{2}{c}{$\begin{array}{c}\text { Decomposed casein } \\
(\mu \mathrm{g} \mathrm{N} / \mathrm{m} l)\end{array}$} \\
\cline { 2 - 6 } Protozoa fraction ${ }^{1,2)}$ & Test 1 & Test 2 & Test 1 & Test 2 \\
\hline \multirow{4}{*}{ time $(\mathrm{min})$} & 0 & 16 & 18 & - & - \\
& 30 & 32 & 56 & 16 & 38 \\
& 60 & 45 & 96 & 29 & 78 \\
& 90 & 58 & 142 & 42 & 124 \\
& 120 & 76 & 191 & 60 & 173 \\
& 180 & 107 & 255 & 91 & 237 \\
\hline \multirow{4}{*}{ Holotrichs } & 0 & 9 & 5 & - & - \\
& 30 & 15 & 11 & 6 & 6 \\
& 60 & 16 & 10 & 7 & 5 \\
& 90 & 16 & 12 & 7 & 7 \\
& 120 & 17 & 12 & 8 & 7 \\
& 180 & 19 & 14 & 10 & 9 \\
\hline
\end{tabular}

1) Protozoa nitrogen : In entodiniomorphid protozoa fraction,

$256 \mu \mathrm{g} / \mathrm{m} l$ in Test 1 , and $305 \mu \mathrm{g} / \mathrm{m} l$ in Test 2 .

In holotrich protozoa fraction,

$368 \mu \mathrm{g} / \mathrm{m} l$ in Test 1 , and $541 \mu \mathrm{g} / \mathrm{m} l$ in Test 2.

2) Composition of protozoa $\left(\times 10^{3} / \mathrm{m} l\right)$ :

Entodiniomorphid protozoa fraction

Holotrich protozoa fraction

\begin{tabular}{|c|c|c|c|c|c|c|}
\hline \multirow{2}{*}{\multicolumn{2}{|c|}{ Entodiniomorphs }} & \multicolumn{2}{|c|}{ Holotrichs } & \multirow{2}{*}{\multicolumn{2}{|c|}{$\begin{array}{l}\text { Entodiniomorphs } \\
\text { large small }\end{array}$}} & Holotrichs \\
\hline & & large & small & & & large small \\
\hline & 600 & 0 & 4 & 0 & 13 & 74 \\
\hline & 720 & 0 & 6 & 3 & 10 & 83 \\
\hline
\end{tabular}

medium of entodiniomorphs was higher than in the medium of holotrichs, protozoa nitrogen in the former culture medium was almost equal to that in the latter. Therefore, the results shown in Table 1 suggest that entodiniomorphid protozoa excrete extra-cellular protease into the culture medium during the incubation, while that it is scarcely excreted by holotrich protozoa.

ONODERA and KANDATsu ${ }^{5)}$ reported that soluble casein was decomposed by holotrich protozoa but not by entodiniomorphiod protozoa, and that insoluble casein particle was decomposed by the latter. Furthermore, ONoDERA et al. ${ }^{10)}$ observed that entodiniomorphid protozoa didn't decompose soluble casein even when it was ingested with carbon powder. Some contradictions may exist between these and the results of this study, but the cause is not clear at this time.

ABOU AKKADA and How ARD ${ }^{11)}$ and ONODERA et al. ${ }^{10)}$ obtained a entodiniomorphid protozoa fraction after destroying holotrich protozoa by perincubation with salt buffer solution containing D-mannose. When we tried this method, however, holotrich protozoa could not be eliminated completely. In this study, protozoa were fractionated into holotrichs and entodiniomorphs by settling and the successive centrifugation of rumen liquid obtained after feeding when holotrich protozoa were remarkably higher in numbers than before feeding ${ }^{12,13)}$. As shown in the footnote of Table 1, the fractiona- 


\section{SHINCHi and ABE}

tion was satisfactorily achieved by this method.

The rumen bacteria attached to the surface of rumen ciliate protozoa ${ }^{8)}$, and also free bacteria inevitably included in culture medium, may affect the proteolytic activity of extra-cellular crude enzyme solution, because rumen bacteria are known to excrete proteolytic enzymes outside the cell ${ }^{14-16}$. It has been reported that $20 \%$ of the

Table 2. Decomposition of casein by isolated bacterial suspension ${ }^{11}$

\begin{tabular}{|c|c|c|c|c|}
\hline \multirow[b]{2}{*}{ Antiobiotics $^{2)}$} & \multirow{2}{*}{$\begin{array}{l}\text { Culture } \\
\text { time(hr) }\end{array}$} & \multicolumn{2}{|c|}{ NPN in culture medium $(\mu \mathrm{g} / \mathrm{m} l)$} & \multirow{2}{*}{$\begin{array}{c}\text { Dcomposed casein } \\
(\mu \mathrm{g} \mathrm{N} / \mathrm{m} l)\end{array}$} \\
\hline & & Without casein & With casein & \\
\hline \multirow{7}{*}{ Not added } & 0 & 4 & *3) & - \\
\hline & 1 & 4 & 22 & 18 \\
\hline & 2 & 4 & 35 & 31 \\
\hline & 3 & 4 & 54 & 50 \\
\hline & 5 & 4 & 96 & 92 \\
\hline & 8 & 3 & 148 & 45 \\
\hline & 20 & 2 & 373 & 371 \\
\hline \multirow{7}{*}{ Added } & 0 & 4 & *3) & - \\
\hline & 1 & 4 & 20 & 16 \\
\hline & 2 & 5 & 37 & 32 \\
\hline & 3 & 5 & 51 & 46 \\
\hline & 5 & 6 & 80 & 74 \\
\hline & 8 & 7 & 117 & 110 \\
\hline & 20 & 7 & 324 & 317 \\
\hline
\end{tabular}

1) Bacterial nitrogen $: 60 \mu \mathrm{g} / \mathrm{ml}$.

2) Fifty $\mu \mathrm{g}$ each of penicilin $\mathrm{G}$ potassium, streptomycin sulfate, kanamycin sulfate and chloromycetin powder were added per $\mathrm{m} l$ medium.

3) Not determined.

Table 3. Decomposition of casein by the extra-cellular crude enzyme solution pre-

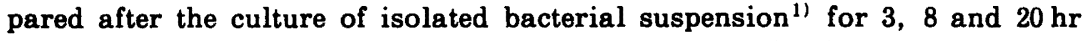

\begin{tabular}{|c|c|c|c|c|c|c|c|}
\hline \multirow{3}{*}{ Antibiotics $^{2}$} & \multirow{3}{*}{$\begin{array}{l}\text { Incubation } \\
\text { time (min) }\end{array}$} & \multicolumn{3}{|c|}{ NPN in incubation medium $(\mu \mathrm{g} / \mathrm{m} l)$} & \multirow{2}{*}{\multicolumn{3}{|c|}{$\frac{\text { Decomposed casein }(\mu \mathrm{g} \mathrm{N} / \mathrm{m} l}{\text { Culture time }(\mathrm{hr}) \text { of bacteria }}$}} \\
\hline & & \multicolumn{3}{|c|}{ Culture time(hr)of bacteria } & & & \\
\hline & & 3 & 8 & 20 & 3 & 8 & 20 \\
\hline \multirow{5}{*}{ Not added } & 0 & 15 & 15 & 15 & - & - & - \\
\hline & 30 & 15 & 16 & 18 & 0 & 1 & 3 \\
\hline & 60 & 15 & 16 & 18 & 0 & 1 & 3 \\
\hline & 90 & 18 & 17 & 18 & 3 & 2 & 3 \\
\hline & 180 & 21 & 23 & 22 & 6 & 8 & 7 \\
\hline \multirow{5}{*}{ Added } & 0 & 15 & 19 & 21 & - & - & - \\
\hline & 30 & 17 & 19 & 22 & 2 & 0 & 1 \\
\hline & 60 & 18 & 21 & 24 & 3 & 2 & 3 \\
\hline & 90 & 19 & 22 & 25 & 4 & 3 & 4 \\
\hline & 180 & 20 & 24 & 27 & 5 & 5 & 6 \\
\hline
\end{tabular}

1) Bacterial nitrogen $: 60 \mu \mathrm{g} / \mathrm{m} l$.

2) Fifty $\mu$ g each of penicilin G potassium, streptomycin sulfate, kanamycin sulfate and chloromycetin powder were added per $\mathrm{ml}$ medium. 


\section{Rumen Protozoa Producing Extra-Cellular Protease}

protease produced by Bacteroides amylophilus are liberated into the growth medium, and that its production is proportional to the concentration of ammonium sulfate and maltose added to the medium ${ }^{14)}$. HAzLewood et al. ${ }^{15)}$ showed that $90 \%$ of the proteolytic activity in the culture medium of Bacteroides ruminocola were derived from cell-associated protease at $16 \mathrm{hr}$ of incubation, but the percentage decreased according to the time of incubation.

In order to know the influence of bacteria on the production of extra-cellular

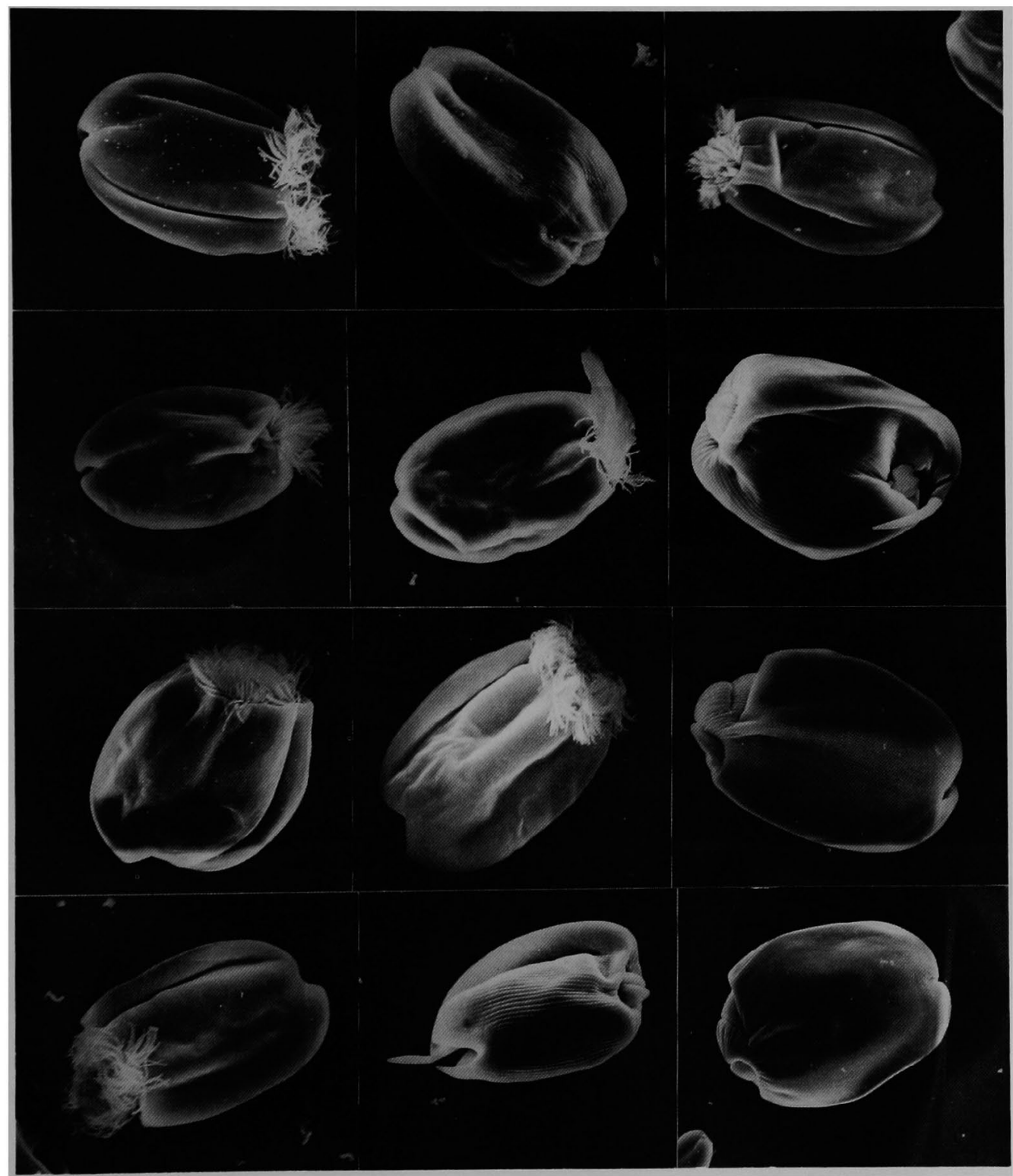

Fig. 2. Scanning electron micrographs of entodiniomorphid protozoa washed twice with sugar-fatty acid ester solution and then washed 5 times with B-9 buffer solution. 
protease, two experiments were executed. In the first, the influence of bacteria possibly contaminated in the medium was examined.

As showen in table 2, casein was degraded when it was added to bacterial suspension and cultured up to $20 \mathrm{hr}$. The addition of antibiotics to the suspension inhibited proteolysis though incompletely. While, as shown in Table 3, casein was hardly decomposed irrespectively of antibiotics when it was incubated for $3 \mathrm{hr}$ with extracellular crude enzyme solutions, which were prepared by centrifuging bacterial suspension cultured for 3,8 and $20 \mathrm{hr}$. These results seeme to suggest that bacterial protease would be largely associated with cells, and precipitated by centrifugation without being liberated from cells. Therefore, it seemes unreasonable to attribute the extracellular proteolytic activity in entodiniomorphid fraction to the contamination of bacteria into this fraction.

Secondly, entodiniomorphid protozoa were washed with sugar-fatty acid ester to eliminate bacteria attached to the surface of these organisms. Fig. 2 shows the effect of washing ciliate protozoa with the solution of sugar-fatty acid ester. After the washing, few bacteria were observed on the surface of entodiniomorphid protozoa by scanning electron microscopy. As shown in Table 4, the proteolytic activity of extracellular crude enzymes was slightly higher in the culture medium of protozoa unwashed with the sugar-fatty acid ester than in that of washed protozoa. However, because the number of protozoa in the former culture medium was more higher than in the latter, the protozoa nitrogen was $228 \mu \mathrm{g} / \mathrm{ml}$ in the former culture medium and $196 \mu \mathrm{g} /$ $\mathrm{ml}$ in the latter, resulting in that the proportion of decomposed casein per protozoa nitrogen in the culture medium was similar for both unwashed and washed protozoa. These results suggest that any possible attachment of bacteria to the surface of entodiniomorphid protozoa had little influence on the proteolytic activity of extra-

Table 4. Effect of washing ciliate protozoa ${ }^{1}$ with $\mathrm{SFAE}^{2)}$ on the proteolytic activity of extra-cellular enzyme solution

\begin{tabular}{|c|c|c|c|c|}
\hline $\begin{array}{r}\text { Incu } \\
\text { Treatment tin } \\
\end{array}$ & $\begin{array}{l}\text { sbation } \\
\operatorname{me}(\min )\end{array}$ & $\begin{array}{l}\text { NPN in incubation } \\
\text { medium }(\mu \mathrm{g} / \mathrm{m} l)\end{array}$ & $\begin{array}{l}\text { Decomposed casein } \\
(\mu \mathrm{g} \mathrm{N} / \mathrm{m} l)\end{array}$ & $\begin{array}{c}\text { Decomposed casein per } \\
\text { protozoa nitrogen }\end{array}$ \\
\hline \multirow{4}{*}{ Unwashed } & 0 & 14 & - & - \\
\hline & 30 & 65 & 51 & 0.22 \\
\hline & 60 & 125 & 111 & 0.49 \\
\hline & 90 & 188 & 174 & 0.76 \\
\hline \multirow{4}{*}{$\begin{array}{l}\text { Washed with } \\
\text { SFAE }\end{array}$} & 0 & 13 & - & - \\
\hline & 30 & 60 & 47 & 0.24 \\
\hline & 60 & 114 & 101 & 0.52 \\
\hline & 90 & 172 & 159 & 0.81 \\
\hline \multirow{3}{*}{\multicolumn{2}{|c|}{ 1) }} & oa $\left(\times 10^{3} / \mathrm{m} l\right):$ Entod & liniomorphids & Iolotrichs \\
\hline & & larg & small & rge small \\
\hline & & c & 522 & 2 \\
\hline \multicolumn{5}{|c|}{ 2) SFAE : Sugar-fatty acid ester. } \\
\hline \multicolumn{5}{|c|}{ 3) Protozoa nitrogen : $\begin{array}{r}228 \mu \mathrm{g} / \mathrm{ml} \text { i } \\
196 \mu \mathrm{g} / \mathrm{ml} \text { i }\end{array}$} \\
\hline
\end{tabular}


cellular enzyme solution.

In conclusion, it is considered that the extra-cellular proteolytic activity wold be principally attributed to entodiniomorphid protozoa, and that the influence of bacteria on this activity would be small enough to be neglected.

\section{References}

1) Ueda, Y., R. Onodera and M. Kandatsu, Jpn. J. Zootech. Sci., $45: 652-656.1975$.

2) Shinchi, S. and M. Kandatsu, Jpn. J. Zootech. Sci., $52: 861-868.1981$.

3) Shinchi, S. and M. Kandatsu, Jpn. J. Zootech. Sci., $54: 290-296.1983$.

4) Shinchi, S., T. Iтон, M. Abe and M. Kandatsu, Jpn. J. Zootech. Sci., $57: 89-96$. 1986.

5) ONodera, R. and M. Kandatsu, Jpn. J. Zootech. Sci., $41:$ 307-313. 1970.

6) ONodera, R. and M. Kandatsu, Jpn. J. Zootech. Sci., $41: 343-348.1970$.

7) Harteree, E.F., Anal. Biochem. $48: 422-427.1972$.

8) Imai, S. and K. Ogimoto, Jpn. J. Vet. Sci., 40:9-19. 1978.

9) Kurihara. Y., J. Jpn. Vet. Med. Assoc. $22: 132-153.1969$.

10) Onodera, R., Y. Toyofuku, S. Fujita, S. Nakagawa and M. Kandatsu, Jpn. J. Zootech. Sci., $45: 652-656.1974$.

11) Aвou AkKada, A.R. and B.H. Howard, Biochem. J. $76: 445-451.1960$.

12) Abe, M., T. IrIKI, N. Tobe and H. Shibui, Appl. Environ. Microbiol., $41: 758-765$. 1981.

13) Abe, M., Y. Suzuki, H. Okano and T. IRIki., Jpn. J. Zootech. Sci., 54 : 457-462. 1983.

14) BlackBURN, T.H., J. gen. Microbiol., $53: 27-36.1968$.

15) Hazlewood, G.P., G.A. Jones and J.L. Mangan, J. gen. Microbiol., 123: 223-232. 1981.

16) Hazlewood, G.P. and R. Edward, J. gen. Microbiol., 125, 11-15. 1981.

細胞外蛋白質分解酵素を産生する反忽胃内繊毛虫の 種類とその活性に及ぼす細菌の影響

\section{新地修士・阿部又信}

麻布大学獣医学部, 相模原市 229

細胞外人蛋白質分解酵素を分泌する瀻毛虫の種類と， その活性に及ぼす織毛虫の体表付着細菌および遊離細菌 の影敬について検討した。第一胃フィステル装着牛から 採取した反妿胃液加ら緎毛虫之細菌を分離し，前者は貞 毛虫と全毛虫とに分画した。 てれらの微生物区分を飢餓 培養後に遠沈して細胞外粗醉素液を調製し，そのカゼイ ン分解能から細胞外蛋白質分解活性を求めた。 その結果 は以下に示す通りであった。

1）細胞外蛋白質分解活性は坌毛虫の培養後に調製し た粗䤃素液にのみ認められ，全毛虫のそれには認められ なかった。
2）紷毛虫の体表付着細菌を除去するため, ショ糖脂 肪酸エステルで洗海した紸毛虫の細胞外蛋白質分解活性 は洗㴖しない織毛虫のそれと差がなかった。

3）細菌はカゼインを分解したが，細菌培養液を遠沈 して得た上清液中には蛋白質分解活性がほとんど認めら れなかった。

4）以上の結果は, 細胞外蛋白質分解活性が主として 宔毛虫の産生する醉素によるものであり, 遊離細菌また は付着細菌の影䈏はほとんどないととを示唆するあのと 考えられた。日畜会報， $58(1) ： 72-79,1987$ 